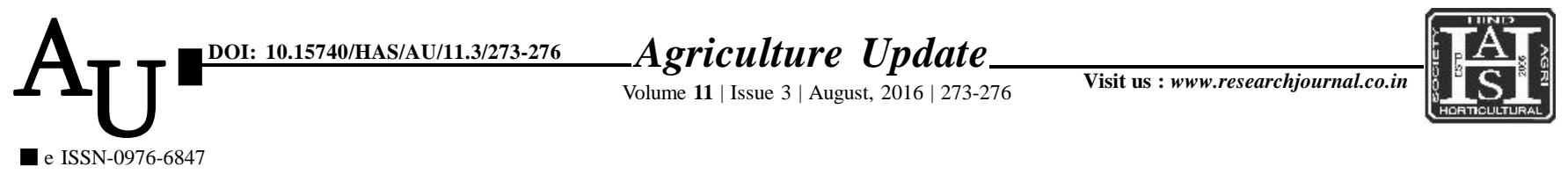

\title{
Research Article: : Ergonomic evaluation of pedal operated arecanut dehusker with women workers in the Konkan region of Maharatshtra
}

\author{
Article Chronicle: \\ Received : \\ 02.05.2016; \\ Revised : \\ 01.07.2016; \\ Accepted : \\ 12.07.2016
}

KeY WoRdS :

Ergonomic evaluation, Arecanut dehusker

\section{V.V. AWARE, SEEMA V. AWARE, P.U. SHAHARE, N.A. SHIRSAT, M.R. PATIL AND CHHAYA R. KAVITKAR}

SUMMARY : Dried arecanut are dehusked at farmer's house or at small scale processing units by manual labour using country kitchen tool having a wooden plank and curved MS blade. Traditional dehusking method is time consuming, highly labour intensive, uneconomical and above all very unsafe for fingers and palms. The developed pedal operated arecanut dehusker was evaluated with nine female workers to check the suitability of the machine for women workers. Average age, weight and stature of the subjects were $26.1( \pm 8.5)$ years, $46.7( \pm 9.6) \mathrm{kg}$ and $158( \pm 6) \mathrm{cm}$, respectively. While average $\mathrm{HR}$ max and $\mathrm{VO}_{2}$ max were $193.9( \pm 8.5) \mathrm{bpm}$ and $1.47( \pm 0.3) 1 / \mathrm{min}$, respectively. The mean heart rate, oxygen consumption rate and energy expenditure rate for nine subjects were $136.6 \mathrm{bpm}, 0.8 \mathrm{l} / \mathrm{min}$ and $16.56 \mathrm{~kJ} / \mathrm{min}$, respectively. The work is under 'Very heavy' category (Sen, 1969).

How to cite this article : Aware, V.V., Aware, Seema V., Shahare, P.U., Shirsat, N.A., Patil, M.R. and Kavitkar, Chhaya R. (2016). Ergonomic evaluation of pedal operated arecanut dehusker with women workers in the Konkan region of Maharatshtra. Agric. Update, 11(3): 273-276, DOI : 10.15740/HAS/AU/11.3/273-276.

\section{V.V. AWARE}

Department of Farm Machinery and Power, College of Agricultural Engineering and Technology, Dr. B.S. Konkan Krishi Vidyapeeth, Dapoli, RATNAGIRI (M.S.) INDIA

See end of the article for authors' affiliations 